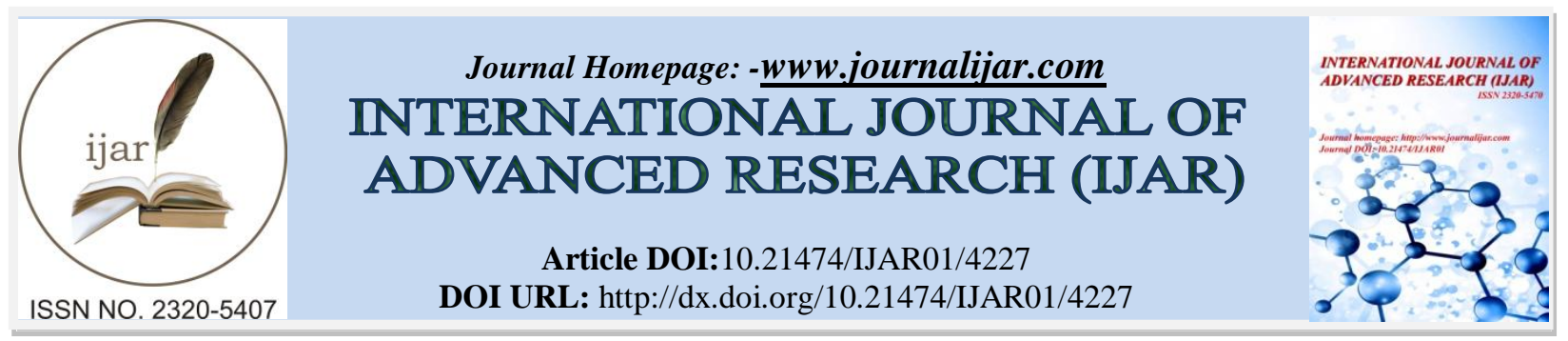

RESEARCH ARTICLE

\title{
ANTIVIRAL ACTIVITY OF SECONDARY METABOLITES PRODUCED BY STREPTOMYCES SPECIES ISOLATED FROM EGYPTIAN SOIL.
}

\section{Heba Ali Abd El Gaied ${ }^{1}$, Abd El Gawad Mohammed Hashem ${ }^{2}$, Aly Mohamed Fahmy ${ }^{3}$ and Marwa Tarek El-} Rakaiby ${ }^{4}$.

1. In process control manager of diphtheria and tetanus plant, the holding company for the production of vaccines, sera and drugs (vacsera).

2. Professor of microbiology and immunology, faculty of pharmacy, British university, Egypt.

3. Head of R \& D sector, the holding company for the production of vaccines, sera and drugs(vacsera).

4. Lecturer of microbiology and immunology, faculty of pharmacy Cairouniversity, Egypt.

\section{Manuscript Info}

Manuscript History

Received: 15-5-2017

Final Accepted: 18-5-2017

Published: $\operatorname{xxxxxxxxxx}$

Key words:-

Actinomycetes, secondary metabolites, antiviral, Hepatitis A virus, Herpes simplex-2, vesicular stomatitis virus, silver nanoparticles.

\section{Abstract}

Virus infections pose significant global health challenges, due to the emergence of resistant viruses. Therefore, it is imperative that safe and conventional antiviral drugs be developed. In the present study, Actinomycetes isolated form Egyptian soil samples were used to investigate the possibility of acquiring antiviral activity from their metabolites by testing against three selected virus models. Results revealed that the sixth fraction purified from isolate (H47/60) metabolites induced significant reduction of virus infectivity titer recording $4.13 \pm 0.181 \log _{(10)} / \mathrm{ml}, 2.79 \pm 0.110 \log _{(10)} / \mathrm{ml}$ and $3.38 \pm$ $0.185 \log { }_{(10)} / \mathrm{ml}$ for HAV, HSV-2 and VSV respectively. Further evaluation of the antiviral activity of the metabolite against three types of viruses was attempted by conjugation to silver nanoparticles.

Copy Right, IJAR, 2017,. All rights reserved.

\section{Introduction:-}

Actinomycetes are unicellular, gram-positive bacteria that belong to the order Actinomycetales with highguanine and cytosine $(\mathrm{G}+\mathrm{C})$ content in their DNA (Pahari et al., 2016). To our day, most of the discovered bioactive compounds were produced from actinomycetes (Janardhan, 2014). A wide range of actinomycetes secondary metabolites have various medical importance, for example: they yielded antibiotics, anticancer drugs, insecticides, herbicides and antiviral drugs (Arasu et al., 2016, Grasso et al., 2016). Actinomycetes are found in many habitats, such as freshwater, sea water, cold and warm blooded animals and composts; however, soil is their most important habitat (Van Elsas and Smit, 1995).

Previous studies reported the isolation of antiviral metabolites from actinomycetes, as a natural active compound that could offer high chemical variations with novel lead structures than standard combinatorial chemical compounds (Kitazato, et al., 2007). Yakugaku Zasshi (2004) found that Streptomyces microflavus strain produced at least 13 fattiviracin derivatives (FV-1 to FV-13) which possessed potent activity against enveloped DNA viruses such as the herpes family, HSV-1, and VZV and enveloped RNA viruses such as influenza A and B viruses, and three strains of HIV-1 (Divakar, 2013).

Corresponding Author: -Heba Ali Abd El Gaied.

Address: - Diphtheria and tetanus plant, the Holding company for the production of vaccines, sera and drugs (vacsera). 
Nanotechnology has been used to develop nanoparticle-based targeted drug carriers (Falanga et al., 2011; HallajNezhadia et al., 2010). The use of nanoparticles can be extended to develop antivirals that act by interfering with the viral infection, particularly during attachment and entry. The action of bactericidal effect of $\mathrm{Ag}+$ ions in silver nanoparticles depends on suppressing the respiratory enzymes and electron transport components in addition to the interference with DNA functions ( $\mathrm{Li}$ et al., 2006). In the present study, Three virus types were selected to cover both DNA and RNA viruses; Hepatitis A, Herpes simplex virus-2 and Vesicular Stomatitis representing positive-sense single-stranded RNA virus, double-stranded, DNA and negative -sense single-stranded RNA respectively.

The antiviral properties of silver nanoparticles were studied on the three virus models alone and in combination with the most potent antiviral metabolites extracted from Egyptian actinomycetes isolates, under optimized cultural conditions.

\section{Materials and Methods:-}

Collection of soil samples:-

Sixty soil samples were collected from different Egyptian localities (Table 1). The samples were withdrawn from a depth of approximately $20 \mathrm{~cm}$ using scoops (Mathur et al., 2012). The collected samples were then placed in polyethylene bags and labeled. The samples stored in the refrigerator $\left(2-8^{\circ} \mathrm{C}\right)$ till further testing.

\section{Isolation and purification of actinomycete isolates:-}

One gram of each soil sample was serially diluted in distilled water followed by inoculation on starch casein agar medium plates to isolate Actinomycetes. The plates were incubated at $35^{\circ} \mathrm{C}$ for $72 \mathrm{hrs}$ (Srinivasan et al., 1991). White pin-point colonies, characteristic of actinomycetes were selected and purified into starch nitrate agar plates. The selected strains were further purified by multiple streaking methods, then the purified actinomycetes colonies were scraped from the agar plate, dipped into Trypticase Soya Broth medium. The flasks were incubated at $28 \pm 2{ }^{\circ} \mathrm{C}$ in a shaker incubator at $200 \mathrm{rpm}$ for 5-7 days followed by centrifugation at $14000 \mathrm{rpm}$ at $4^{\circ} \mathrm{C}$ for 15 minutes (Bosserman et al., 2010). The crude extract was monitored for its safety on Vero cell line using 3-(4, 5Dimethylthiazol-2-yl)-2, 5-dipheyltetrazolium bromidefor (MTT) assay (Stockert et al., 2012).

\section{Primary Evaluation of Metabolites for existence of Antiviral Activity:-}

Cytopathic inhibition assay was used for primary screening of crude metabolites (Mosmann, 1983) using three virus models (Hepatitis A virus, Herpes simplex-2 and vesicular stomatitis virus) supplied from R \& D sector, VacseraEgypt. Virus infectivity titers were $10^{6.66}, 10^{6.00}$ and $10^{7.66} \mathrm{TCID}_{50} / \mathrm{mL}$ respectively determined according to Reed and Muench (Reed and Muench, 1938).

Vero cells $\left(2 \times 10^{5} / \mathrm{ml}\right)$ provided by the Tissue Culture Department (VACSERA)pre-cultured for $24 \mathrm{~h}$ in a humidified $37^{\circ} \mathrm{C}$ incubator with $5 \% \mathrm{CO} 2$ in a 96 -well microtiter plate. The safe concentration of extracted metabolite was used as $100 \mu \mathrm{L} / \mathrm{ml}$ to treat pre-cultured $96-$ well Vero plate for $24 \mathrm{~h}$, untreated control plate was included. Treatment media was decanted and each of selected viruses under study was dispensed regarding virus dilution $\left(10^{-1}-10^{-8}\right)$ as $100 \mu \mathrm{L} /$ well. Infected cells were monitored daily using inverted microscope to record the wells that showed cytopathic effect (CPE), infectivity titers were determined according to Reed and Muench (Reed and Muench, 1938).

The isolate showing maximum antiviral effect was subjected for re-cultivation and optimization of culture conditions for antiviral metabolites extraction and identification.

\section{Identification of selected isolate characteristics:-}

The isolate that exhibited the most potent antiviral metabolite was identified on the basis of morphological, cultural and physiological and biochemical behaviors. Morphological and cultural characteristics were studied on different media following the instructions given by the International Streptomyces Project (ISP) (Shirling and Gottlieb, 1966). Different media were used including starch casein agar medium; ISP-2; ISP-3; ISP-4; ISP-5; ISP- 6 and ISP-7 (Shirling and Gottlieb, 1966).

\section{Macroscopic and microscopic identification of the isolate:-}

Macroscopic identificationincludes determination of aerial mass color, the color of substrate mycelium and presence of soluble colors other than melanoid pigments ( $\mathrm{Li}$ et al., 2016), whereas microscopic identification of the isolate determines the micro-morphological characteristic of spore-bearing hyphae, spore morphology and surface (Shirling and Gottlieb, 1966). 


\section{Physiological characterization:-}

Using carbon utilization test (Oskay et al., 2004); sodium chloride tolerance reaction (Sengupta et al., 2015); growth temperature and $\mathrm{pH}$ range; (Arul Jose et al., 2014).

\section{Biochemical characterization:-}

Using gram staining (Duraipandiyan et al., 2010); IMViC test (MacFaddin, 2000); H2S production test; motility test (Schau, 1986); Gelatin hydrolysis test; Nitrate reduction test (Murray B and Jorgensen, 2007); Catalase production test (Chun et al., 2000); Casein hydrolysis test (Wehr et al., 2004); Ornithine decarboxylase test (MacFaddin, 2000); Starch hydrolysis test (Garcia, 2010).

\section{Phylogenetic identification:-}

Molecular identification and Phylogenetic analysis done in Global institute research services solution (GIRSS) for isolate under study include: genomic DNA extraction (Miller et al., 1988), using Wizard Genomic DNA purification Kit (Promega), PCR amplification of the 16S ribosomal DNA using eubacterial universal primers F27 with the sequence 5'-AGAGTTTGATCMTGGCTCAG-3' and R1492 with the sequence 5'TACGGYTACCTTGTTACGACTT-3' (Heuer et al., 1997), The PCR product was examined using 1.5\% agarose gel in TBE buffer ( $\mathrm{pH}$ 8.5), the PCR product was purified using PCR purification kit (Qiagen, Germany) and sequencing of the PCR products using an ABI PRISM 310 DNA sequencer and ABI PRISM Big Dye Terminator Cycle Sequencing in Vacsera sequencer unit (Frank et al., 2008). Sequences were then analyzed using Blast program to assess the DNA similarities (Altschul et al., 1990).

\section{Optimization of culture Conditions of Selected Isolate:-} Optimization of culture conditions for enhancing metabolite antiviral Activity:-

The antiviral activity was enhanced by manipulating selected physical parameters, whereas $\mathrm{pH}$ levels of the basal media were adjusted from 5 to 10 , followed by adjusting the optimum temperature for growth ranging from $20^{\circ} \mathrm{C}$ to $50^{\circ} \mathrm{C}$ and finally the effect of incubation period (Stockert et al., 2012).

After selecting optimum conditions for the isolate growth the cell-free filtrate was mixed with equal volume of ethyl acetate $(1: 1 \mathrm{~V} / \mathrm{V})$ for extraction of the bioactive compound. The lower aqueous phase was discarded and upper organic phase was concentrated in a in a rotary evaporator at $40^{\circ} \mathrm{C}$ for 24 hours to obtain the crude extract (Gebreyohannes et al., 2013). The crude extract was then purified using column chromatography. Finally, obtained fractions were screened for antiviral activity; the fraction possessing antiviral activity was further purified and analyzed in Micro Analytical Center Cairo University.

Storage of the isolate: As glycerol stocks and lyophilized form (Kieser et al., 2000).

Partial characterization of the antiviral Metabolite:-

Performing spectral studies on purified band possessing antiviral activity as UV, IR, mass spectrum and ${ }^{1} \mathrm{HNMR}$; all measurements were performed in Micro Analytical Center Cairo University.

\section{Synthesis of Silver Nanoparticles:-}

The silver nanoparticles (AgNPs) were prepared by chemical reduction method according to Ratyakshi and Chauhan (2009).

Solution A was prepared by dissolving $0.17 \mathrm{~g} \mathrm{AgNO} 3$ in $100 \mathrm{ml}$ distilled water to prepare $1 \mathrm{mM}$ of $\mathrm{AgNO} 3$ stock solution; whereas solution B prepared by dissolving $0.3 \mathrm{~g}$ sodium citrate in $100 \mathrm{ml}$ distilled water to prepare $1 \mathrm{mM}$ of trisodium citrate. Ten milliliter of solution A was diluted to $50 \mathrm{ml}$ in a beaker and heated up while stirring at 400 rpm, after boiling $1 \mathrm{ml}$ of solution B was added and left on the heater till the formation of clear golden yellow color of AgNPs (Ratyakshi and Chauhan 2009). All Nanoparticles characterization (Table 4) and preparation processes were conducted at Agriculture research center, in the Central Lab of Nanotechnology and advanced materials.

\section{Cytotoxicity assay ofsilver Nanoparticles:-}

The cytotoxic activity of two-fold serial dilution of AgNPs against Vero cell lines incubated for $48 \mathrm{~h}$ in $5 \% \mathrm{CO}_{2}$ humidified incubator. Cell viability was evaluated by the 3-(4, 5-dimethyl-2-thiazolyl)-2, 5-diphenyl-tetrazolium bromide (MTT) assay (Stockert et al. 2012). 


\section{Evaluation antiviral activity of purified fraction combined to AgNPs:-}

Pre-cultured 96-well Vero plate treated with $100 \mu \mathrm{L} / \mathrm{ml}$ of purified antiviral extract combined to AgNPs safest concentration for $24 \mathrm{hr}$, untreated control plate was included. Treatment media was decanted and virus models were dispensed regarding virus dilution $\left(10^{-1}-10^{-8}\right)$ as $100 \mu \mathrm{L} /$ well. Infected cells were monitored daily for 7 days and infectivity titer was determined according to Reed and Muench (1938) as previous.

\section{Statistical Analysis:-}

All experiments were performed in triplicate, three independent experiments were conducted and the data was presented as mean $\pm \mathrm{SD}$. The two tailed t-test was used to evaluate antiviral activity related to reduction in virus infectivity titer. The results were considered statistically non-significant when p-value was $>0.05$.

\section{Results:-}

Identification of selected isolate $(\mathrm{H47/60})$ Characteristics:-

Characteristics of the isolate on starch nitrate agar medium (Fig 1) showed that the isolate as gram positive, possessing an earthy odor of actinomycetes.

Morphological characteristics of the isolate on different media recommended by the International Streptomyces Project (ISP) were shown in (Table 2), whereas physiological and Biochemical characteristics of isolate were shown in (Table 3). Microscopic examination of isolate (Fig 2) showed spore chains morphology under scanning electron microscope.

\section{Phylogenetic identification of the isolate:-}

The PCR product examined using $1.5 \%$ agarose gel was of $1500 \mathrm{bp}$. Alignment of H47/60 isolate was identified as Streptomyces Avermitilis using Blast program (Query: 81873) and the sequence (436 bp) was deposited in gene bank database under accession number KY778695. The phylogenic tree of the isolate was shown in (Fig 3) as identified using DNA lasergene software.

\section{Optimization of culture conditions for enhancing metabolite antiviral Activity:-}

Streptomyces isolate (H47/60) showed significant increase in antiviral metabolite production at $\mathrm{PH}$ falling between 7 and 8 , incubation temperature falling between $25^{\circ} \mathrm{Cand} 30^{\circ} \mathrm{C}$ and six to seven days incubation period.

\section{Cytotoxicity and antiviral effect of AgNPs:-}

Cytotoxicity of synthesized AgNPs against Vero cells showed $87 \%$ cell death at concentration $1000 \mu \mathrm{g} / \mathrm{mL}$ and the inhibitory concentration $50 \%$ (IC50) was recorded at $62.5 \mu \mathrm{g} / \mathrm{mL}$. In the meantime, the safe concentration was $15.6 \mu \mathrm{g} / \mathrm{ml}$ and was used to evaluate the antiviral potential but was found to induce mild decrease in virus titer.

\section{Antiviral activity of isolate extract and silver nanoparticles:-}

Primary screening of Suez isolate H47/60 revealed reduction of test viruses infectivity titer. After optimization of isolate culture characteristics, the bioactive compounds from crude ethyl acetate extract were purified using Silica gel column chromatography according to (Afifi et al. 2012). Eight eluents were collected from the crude extract sample, antiviral activities of these eluents were performed, the sixth fraction (fraction no.6) showed noticeable antiviral activity. In mean while purified fraction obtained after optimization of culture conditions alone and in combination to silver nanoparticles exhibited noticeable reduction of virus infectivity titer (table 5).

\section{Discussion:-}

Vaccination policy is considered as a preemptive first line of defense against most viral infections by developing white blood cells that could combatthe introduced virus and acquire herd immunity (Heymann and Aylward, 2006).).Despite vaccines successes, there are some minor complications (i.e some allergic reaction, immunocompromised individuals are not recommended to use live-attenuated vaccines) (Omer et al., 2009).

Vaccines are considered ineffective on unstable viruses and with patients who has already been infected. These disadvantages were the idea behind modern antiviral drug design to reduce the possible likelihood of various side effects. The strategy of designing drugs that could prevent viral entry or inhibit virus uncoating is of great importance (Bishop, 1999). In our study we isolated actinomycetes from Egyptian soil sample; primary screening of Suez sample (47/60) revealed a noticeable reduction of test viruses infectivity titer. This could suggest that the 
extracted metabolite had the ability to interfere with virus ability to infiltrate a target cell (Vero cell line). Several researchers were able to isolate antiviral metabolites from actinomycetes. Tsunakawa et al., 1992 isolated a new actinomycete strain, Amycolaptosis Orientalis No.Q427-8(ATCC53884) from a soil sample collected in Maharashtra state, India, which produced a complex of new antiviral antibiotics. The quatromicins structural studies suggested that they are a novel type of molecules unrelated to any known antibiotics. Each component of quatromicin exhibited antiviral activity against herpes simplex (Divakar, 2013).

Alignment ofthe 16S rRNA gene identified theisolate as Streptomyces Avermitilis. Streptomyces Avermitilis was recorded as industrial microorganism that produce diverse secondary metabolites like macrocyclic lactones, milbemycin, and avermectins (Komatsu et al., 2013).

Manipulating physical parameters of the culturing conditions was of great value in enhancing antiviral activity. Our result agreed with other researches including Bundale, S. et al., (2015) who developed an efficient fermentation process for the production of secondary metabolites from Streptomyces species by adjusting several cultivation parameters like $\mathrm{pH}$, incubation period and temperature (Bundale et al., 2015).

AgNPs have been reported to possess anti-fungal, anti-inflammatory and anti-viral activity; Remya, RR. et al., (2015) proved that silver nanoparticles exerted antiviral activity against HIV-1 at non-cytotoxic concentrations and that the size and dose concentration of nanoparticles play an important role in inducing cytotoxicity (Remya et al., 2015). In his study on the cytotoxicity of AgNPs recorded $90.5 \%$ and $89.7 \%$ cell death against MCF-7 and Vero cell lines at $1000 \mathrm{mg} / \mathrm{mL}$. The inhibitory concentration 50\% (IC50) against MCF- 7 and Vero cell lines were observed at $7.19 \mathrm{mg} / \mathrm{mL}$ and $66.34 \mathrm{mg} / \mathrm{mL}$ respectively. These findings showed high similarities with our study, in mean time antiviral activity of silver nanoparticle at low concentration may be attributed to their activity at an early stage of viral replication (entry or fusion) by inhibiting the interaction between gp120 and the target cell membrane receptors (Lara et al., 2010).

\section{Acknowledgement:-}

The authors are thankful toMicrobiology and Immunology sector Faculty of Pharmacy Cairo University; the R\&D Sector Holding Company for the Production of Vaccines, Sera and Drugs (Vacsera), and Global institute research services solution (GIRRS) for providing necessary facilities and support to carry out this study.

Table 1: Showing localities and numbersof isolates under study.

\begin{tabular}{|c|c|}
\hline Cairo & 11 samples \\
\hline Assiut Governorate & 5 samples \\
\hline Kaliobeya & 14 samples \\
\hline Coastal Mediterranean area & 10 samples \\
\hline Kafr El Sheikh & 4 samples \\
\hline Suez & 6 samples \\
\hline Damietta & 3 samples \\
\hline Port Said & 7 samples \\
\hline
\end{tabular}

Table 2:- Morphological characteristics of the isolate H47/60 on ISP Media.

\begin{tabular}{|c|c|c|c|c|c|}
\hline Type of Medium & Growth & $\begin{array}{c}\text { Color of } \\
\text { aerial mycelium }\end{array}$ & $\begin{array}{c}\text { Color of } \\
\text { substrate mycelium }\end{array}$ & $\begin{array}{c}\text { Production of } \\
\text { soluble pigment }\end{array}$ \\
\hline ISP 2 & Good & green grey & ochre brown & ochre brown & \\
\hline ISP 3 & Good & green grey & ochre brown & none & none \\
\hline ISP 4 & Good & green grey & ochre brown & ochre brown & \\
\hline ISP 5 & Good & green grey & ochre brown & none & \\
\hline ISP6 & Good & None & ochre brown & ochre brown \\
\hline ISP 7 & Good & green grey & ochre brown & \multicolumn{2}{|c}{} \\
\hline
\end{tabular}


Table 3:-Physiological and biochemical properties of isolate

\begin{tabular}{|c|c|c|c|}
\hline \multirow{2}{*}{\multicolumn{2}{|c|}{$\begin{array}{l}\text { Physiological characteristics } \\
\text { Carbon source utilization }\end{array}$}} & \multicolumn{2}{|c|}{ Biochemical characteristics } \\
\hline & & Indole & positive \\
\hline Glucose & + & Voges-Proskauer & positive \\
\hline L-inositol & + & citrate utilization & positive \\
\hline D-fructose & + & Gelatin & positive \\
\hline Raffinose & + & Starch & positive \\
\hline L- arabinose & + & casein hydrolysis & positive \\
\hline D-mannitol & + & peptonization of milk & positive \\
\hline Rhamnose & + & nitrate reduction & positive \\
\hline Sucrose & - & $\mathrm{H}_{2} \mathrm{~S}$ production test & positive \\
\hline Cellulose & - & Motility & negative \\
\hline D-xylose & - & Methyl-red & negative \\
\hline \multicolumn{2}{|c|}{ Sodium chloride tolerance test } & ornithine decarboxylase & negative \\
\hline $2 \% \mathrm{w} / \mathrm{v} \mathrm{NaCl}$ & + & urease test & negative \\
\hline $5 \% \mathrm{w} / \mathrm{v} \mathrm{NaCl}$ & + & & \\
\hline $7 \% \mathrm{w} / \mathrm{v} \mathrm{NaCl}$ & - & & \\
\hline $10 \% \mathrm{w} / \mathrm{v} \mathrm{NaCl}$ & - & & \\
\hline \multicolumn{4}{|c|}{ Growth temperature range } \\
\hline $20^{\circ} \mathrm{C}$ & + & & \\
\hline $25^{\circ} \mathrm{C}$ & ++ & & \\
\hline $30^{\circ} \mathrm{C}$ & ++ & & \\
\hline $35^{\circ} \mathrm{C}$ & + & & \\
\hline $40^{\circ} \mathrm{C}$ & + & & \\
\hline $50^{\circ} \mathrm{C}$ & - & & \\
\hline \multicolumn{4}{|c|}{ Growth PH range } \\
\hline 5 & + & & \\
\hline 7 & ++ & & \\
\hline 8 & ++ & & \\
\hline 9 & + & & \\
\hline 10 & - & & \\
\hline
\end{tabular}

- For Carbon source utilization test: $(+)$ : indicated that growth on tested carbon was significantly better than on basal while negative (-): indicates that the growth was similar to or less than growth on basal medium without carbon.

- The following grades were used to indicate the extent of growth for sodium chloride tolerance test, different temperature and PH ranges, whereas: $\quad-$ : no growth, +: moderate growth, and ++: good growth.

Table 4:- Silver nanoparticles characterization.

\begin{tabular}{|l|l|}
\hline $\begin{array}{l}\text { High-Resolution } \\
\text { Transmission Electron } \\
\text { Microscope (HRTEM) }\end{array}$ & Showed, spherical shaped particles with average size 5 $\pm 3 \mathrm{~nm}$ \\
\hline Zeta sizer nano ZS & Showed the average particle size 5 nm and net charge $-38.4 \mathrm{mV}$ \\
\hline $\begin{array}{l}\text { Fourier Transform } \\
\text { Infrared Spectroscopy } \\
\text { (FTIR) }\end{array}$ & $\begin{array}{l}\text { Showed a broad absorption band at } 3425 \mathrm{~cm}^{-1} \text { assigned for O-H stretching vibration. } \\
\text { The presence of the sharp peak at } 2922 \mathrm{~cm}^{-1} \text { assigned to C-H stretching vibration. } \\
\text { Also, sharp and strong absorption bands of N-H and C=O group appeared at } 1636 \mathrm{~cm}^{-1} \\
\text { and } 1429 \mathrm{~cm}^{-1} \text { respectively, where } 1058 \mathrm{~cm}^{-1} \text { was assigned to C-N stretching }\end{array}$ \\
\hline Spectrophotometer & $\begin{array}{l}\text { Showed sharp characteristic absorption peak at } 415 \mathrm{~nm} \text { which corresponding to the } \\
\text { plasmonic absorption band of spherical shaped silver nanoparticles }\end{array}$ \\
\hline
\end{tabular}


Table 5:- Screening of isolate metabolite antiviral activity.

\begin{tabular}{|c|c|c|c|}
\hline Antiviral activity & HAV & HSV-2 & VSV \\
\hline Silver nanoparticles & $0.53 \pm 0.07 \log _{(10)} / \mathrm{ml}$ & $0.6 \pm 0.042 \log _{(10)} / \mathrm{ml}$ & $0.69 \pm 0.095 \log _{(10)} / \mathrm{ml}$ \\
\hline Primary metabolite screening & $2.41 \pm 0.13 \log (10) / \mathrm{ml}$ & $1.43 \pm 0.87 \log _{(10)} / \mathrm{ml}$ & $2.17 \pm 0.022 \log _{(10)} / \mathrm{ml}$ \\
\hline Purified fraction & $4.13 \pm 0.181 \log _{(10)} / \mathrm{ml}$ & $2.79 \pm 0.11 \log _{(10)} / \mathrm{ml}$ & $3.38 \pm 0.18 \log _{(10)} / \mathrm{ml}$ \\
\hline $\begin{array}{l}\text { Purified fraction combined to } \\
\text { silver nanocomposite }\end{array}$ & $4.58 \pm 0.07 \log (10) / \mathrm{ml}$ & $3.24 \pm 0.07 \log _{(10)} / \mathrm{ml}$ & $3.99 \pm 0.08 \log _{(10)} / \mathrm{ml}$ \\
\hline
\end{tabular}

Fig 1:- Morphological characteristics of isolate (H47/60)

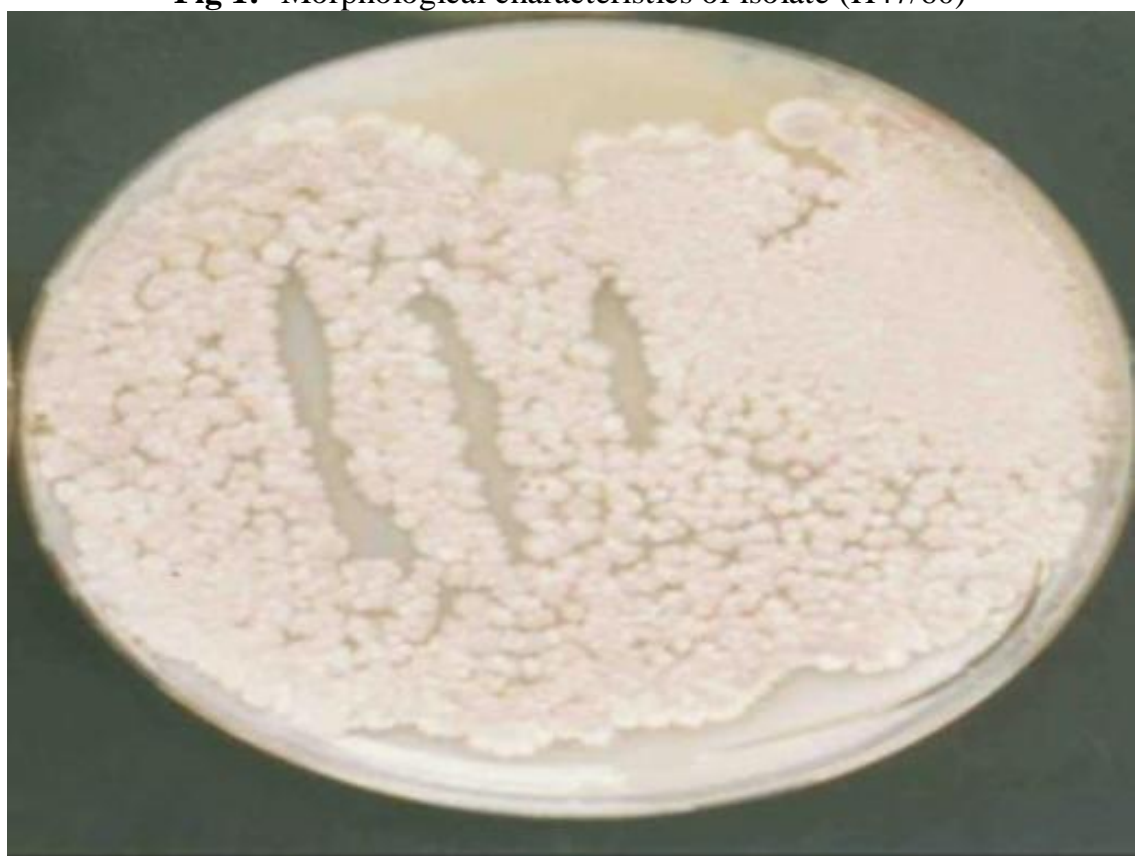

The colony on starch nitrate agar medium is whitish grey in color, mycelium was aerial and white in color; the substrate mycelium was light grey; colony elevation was raised with wrinkled surface and tenaciously adhering to the medium.

Fig 2:- Microscopic examination of isolate (H47/60) under scanning electron microscope.

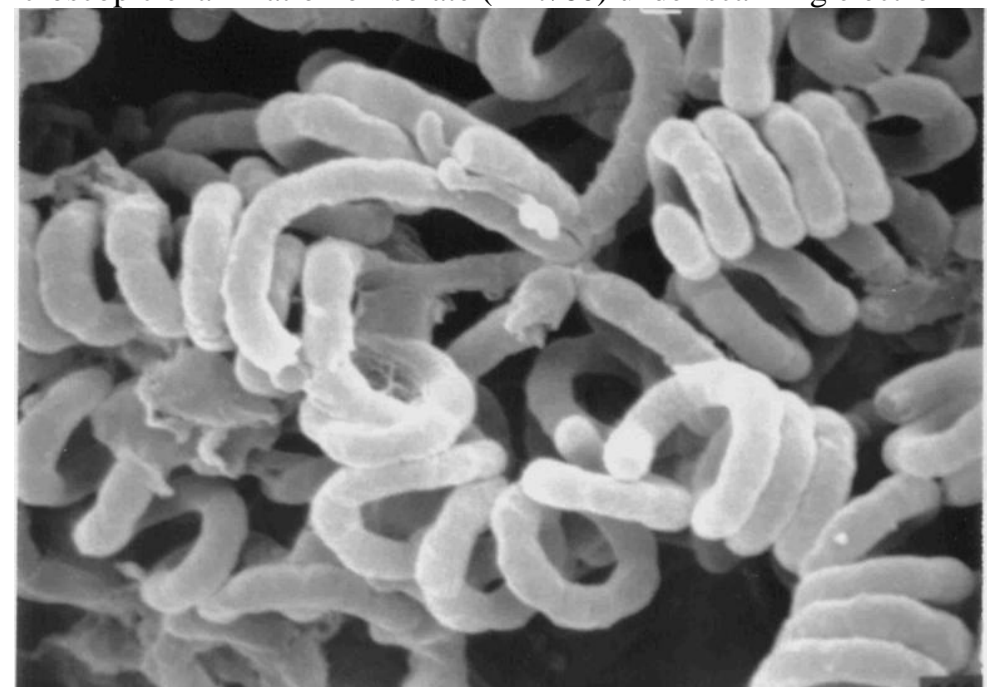

Microscopic examination of spore chains appeared smooth with simple unbranched sporophore. 
Fig 3:- The phylogenic tree of the isolate (H47/60)

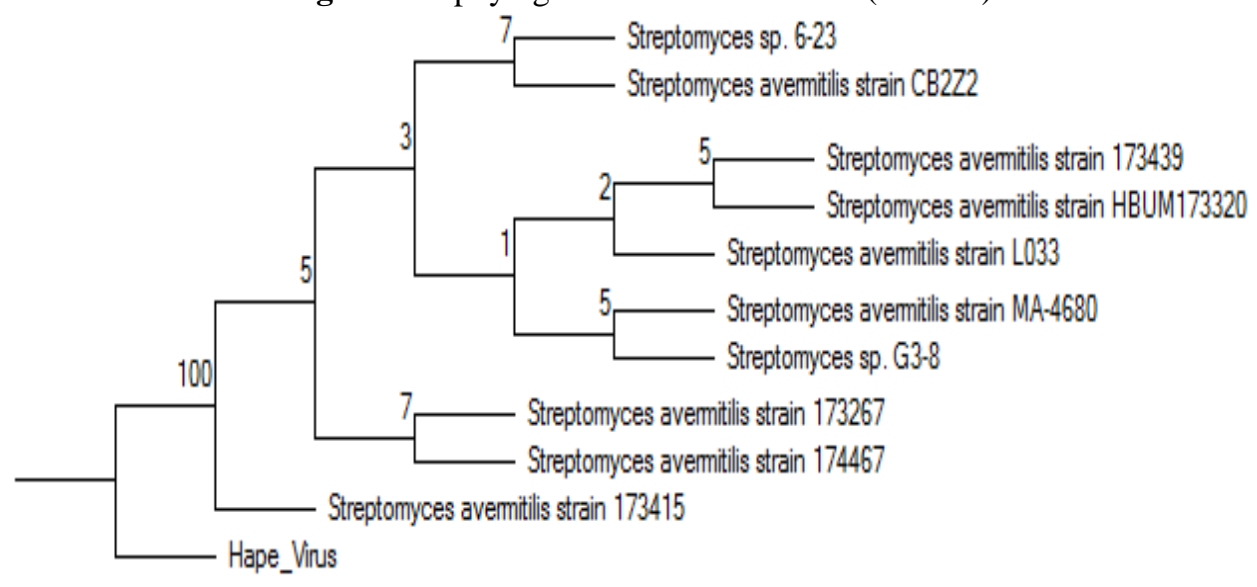

The phylogenic tree obtained by using the Tree view program identified the isolate as Streptomyces Avermitilis strain.

\section{References:-}

1. Afifi, MM. Atta, HM., Elshanawany, AA., Abdoul-Raouf, UM. and El-Adly, AM. (2012). Biosynthesis of hygromycin-B antibiotic by Streptomyces crystallinus AZ151 isolated from Assuit. Egypt. Bacteriol. J, 2, 4665.

2. Altschul, SF., Gish, W., Miller, W., Myers, EW. andLipman, DJ. (1990). Basic local alignment search tool. Journal of molecular biology, 215(3), 403-410.

3. Arasu, MV.,Esmail, GA. and Al-Dhabi, NA. (2016). Hypersaline Actinomycetes and Their Biological Applications.

4. Arul Jose, P., Sivakala, KK.,Rajeswari, P. and Jebakumar, S R D. (2014). Characterization of Antibiotic Producing Rare Actinomycete Nonomuraea sp.

5. Bishop, N. E. (1998). Examination of potential inhibitors of hepatitis A virus uncoating. Intervirology, 41(6), 261-271.

6. Bosserman, MA., Shepherd, MD., Khare,1 MK. and Rohr, J. (2010). Laboratory Maintenance of Streptomyces argillaceus and Streptomyces griseus. Current protocols in microbiology, pp.10E-2.

7. Bundale, S., Begde, D., Nashikkar, N., Kadam, T. and Upadhyay, A. (2015). Optimization of Culture Conditions for Production of Bioactive Metabolites by Streptomyces spp. Isolated from Soil. Advances in Microbiology, 5(06), 441.

8. Chun, J., Bae, KS., Moon, EY., Jung, SO., Lee, H. K. and Kim, SJ. (2000). Nocardiopsiskunsanensis sp. nov., a moderately halophilic actinomycete isolated from a saltern. International journal of systematic and evolutionary microbiology, 50(5), 1909-1913.

9. Divakar, K. (2013). Review on antagonistic actinomycetes-shodhganga. Chapter 10.

10. Duraipandiyan, V., Sasi, AH., Islam, VIH., Valanarasu, M. and Ignacimuthu, S. (2010). Antimicrobial properties of actinomycetes from the soil of Himalaya. Journal de MycologieMédicale/Journal of Medical Mycology, 20(1), 15-20.

11. Falanga, A., Vitiello, M., Cantisani. M., Tarallo, R., Guarnieri, D., Mignogna, E., Netti, P., Pedone, C., Galdiero, M. and Galdiero, S. (2011). A peptide derived from herpes simplex virus type 1 glycoprotein H: membrane translocation and applications to the delivery of quantum dots.Nanomedicine: Nanotechnology, Biology and Medicine, 7(6), pp.925-934.

12. Frank JA, Reich CI, Sharma S, Weisbaum JS, Wilson BA and Olsen GJ (2008). Critical evaluation of two primers commonly used for amplification of bacterial $16 \mathrm{~S}$ rRNA genes. Applied and environmental microbiology, 74(8), 2461-2470.

13. Gebreyohannes, G., Moges, F., Sahile, S. and Raja, N. (2013). Isolation and characterization of potential antibiotic producing actinomycetes from water and sediments of Lake Tana, Ethiopia. Asian Pacific journal of tropical biomedicine, 3(6), 426-435.

14. Grasso, LL., Martino, DC. andAlduina, R. (2016). Production of Antibacterial Compounds from Actinomycetes. 
15. Hallaj-Nezhadia, S., Lotfipour, F. and Dass, CR. (2010). Delivery of nanoparticulate drug delivery systems via the intravenous route for cancer gene therapy. Die Pharmazie-An International Journal of Pharmaceutical Sciences, 65(12), pp.855-859.

16. Heuer, H., Krsek, M., Baker, P., Smalla, K. and Wellington, EM. (1997). Analysis of actinomycete communities by specific amplification of genes encoding 16S rRNA and gel-electrophoretic separation in denaturing gradients. Applied and environmental microbiology, 63(8), 3233-3241.

17. Heymann, D. L., \& Aylward, R. B. (2006). Mass vaccination: when and why. In Mass Vaccination: Global Aspects-Progress and Obstacles (pp. 1-16). Springer Berlin Heidelberg.

18. Janardhan, A., Kumar, A. P., Viswanath, B., Saigopal, D. V. R. and Narasimha, G. (2014). Production of bioactive compounds by actinomycetes and their antioxidant properties. Biotechnology research international.

19. Kieser, T., Bibb, MJ.,Buttner, MJ., Chater, KF. and Hopwood, DA. (2000). General introduction to actinomycete biology. Norwich, England: John Innes Foundation, 1-18.

20. Kitazato, K., Wang, Y., \& Kobayashi, N. (2007). Viral infectious disease and natural products with antiviral activity. Drug DiscovTher, 1(1), 14-22.

21. Komatsu, M., Komatsu, K., Koiwai, H., Yamada,Y., Kozone, I., Izumikawa, M. and Cane, DE. (2013). Engineered Streptomyces avermitilis host for heterologous expression of biosynthetic gene cluster for secondary metabolites. ACS synthetic biology, 2(7), 384-396.

22. Lara, HH., Ayala-Nuñez, NV., Ixtepan-Turrent, L. and Rodriguez-Padilla, C. (2010). Mode of antiviral action of silver nanoparticles against HIV-1. Journal of nanobiotechnology, 8(1), 1.

23. Li Q, Chen X, Jiang Y and Jiang C (2016). Cultural, Physiological, and Biochemical Identification of Actinobacteria.

24. Li, Y., Leung, P., Yao, L., Song, QW. and Newton, E. (2006). Antimicrobial effect of surgical masks coated with nanoparticles. Journal of Hospital Infection, 62(1), pp.58-63.

25. Mathur, N., Paliwal, A., Sharma, P., Kumar, M. and Bhatnagar, P. (2012). Antimicrobial Compound from Streptomyces Isolate Characterized Using HPLC. Universal Journal of Environmental Research \& Technology, 2(4).

26. MacFaddin JF (2000). Biochemical tests for identification of medical bacteria (3rdedn) Lippincott Williams \& Wilkins.

27. Miller, SA., Dykes, DD. and Polesky, HFRN. (1988). A simple salting out procedure for extracting DNA from human nucleated cells. Nucleic acids research, 16(3), 1215.

28. Mosmann T (1983). Rapid colorimetric assay for cellular growth and survival: application to proliferation and cytotoxicity assays. Journal of immunological methods, 65(1-2), pp.55-63.

29. Murray, B. and Jorgensen, L. Pfaller (ed.) (2007). Manual of clinical microbiology, 9th ed. American Society for Microbiology, Washington, DC.

30. Omer, S. B., Salmon, D. A., Orenstein, W. A., Dehart, M. P., \& Halsey, N. (2009). Vaccine refusal, mandatory immunization, and the risks of vaccine-preventable diseases. New England Journal of Medicine, 360(19), 19811988.

31. Pahari, A. K., Dasgupta, D., Patil, R. S., and Mukherji, S. (2016). Emission of bacterial bioaerosols from a composting facility in Maharashtra, India. Waste Management, 53, 22-31.

32. Ratyakshi and Chauhan, RP. (2009)."Colloidal synthesis of silver nano particles". Asian Journal of Chemistry 21, no. 10: 113-116.

33. Reed, LJ. and Muench, H. (1938). A simple method of estimating fifty percent endpoints. American journal of epidemiology, 27(3), 493-497.

34. Remya, RR.,Rajasree, SR., Aranganathan, L. and Suman, TY. (2015). An investigation on cytotoxic effect of bioactive AgNPs synthesized using Cassia fistula flower extract on breast cancer cell MCF-7. Biotechnology Reports, 8, 110-115.

35. Schau, HP. (1986). JF MacFaddin, Media for Isolation-Cultivation-Identification-Maintenance of Medical Bacteria, Volume I. XI+ 929 S., 163 Abb., 94 Tab. Baltimore, London 1985. Williams and Wilkins. \$90.00. ISBN: 0-683-05316-7. Journal of Basic Microbiology, 26(4), 240-240.

36. Sengupta, S., Pramanik, A., Ghosh, A. and Bhattacharyya, M. (2015). Antimicrobial activities of actinomycetes isolated from unexplored regions of Sundarbans mangrove ecosystem. BMC microbiology, 15(1), 1.

37. Shirling, E.B. and Gottlieb, D. (1966). Methods for characterization of Streptomyces speciesInt J SystBacteriol, 16, pp. 313-340.

38. Srinivasan, MC.,Laxman, RS. and Deshpande, MV. (1991). Physiology and nutritional aspects of actinomycetes: an overview. World Journal of Microbiology and Biotechnology, 7(2), pp.171-184. 
39. Stockert, J., Blázquez-Castro, A., Cañete, M., Horobin, RW. and Villanueva, Á. (2012). MTT assay for cell viability: Intracellular localization of the formazan product is in lipid droplets. Actahistochemica, 114(8), pp.785-796.

40. Van Elsas, J. D., and Smit, E. (1995). Some considerations on gene transfer between bacteria in soil and rhizosphere. Molecular Ecology of Rhizosphere Microorganisms: Biotechnology and the release of GMOs, 151164.

41. Wehr, HM., Frank, JF. and American Public Health Association (Eds.) (2004). Standard methods for the examination of dairy products (pp.327-404). Washington, DC: American Public Health Association. 